\title{
Accessibility to Oral Antiviral Therapy for Patients with Chronic Hepatitis $C$ in the United States
}

\author{
Sammy Saab*1,2, Melissa Jimenez ${ }^{2}$, Tiffany Fong ${ }^{2}$, Crystal $\mathrm{Wu}^{2}$, Sherona Bau ${ }^{2}$, Zoha Jamal ${ }^{2}$, \\ Jonathan Grotts ${ }^{3}$ and David Elashoff ${ }^{3}$ \\ ${ }^{1}$ Department of Medicine, University of California, Los Angeles, CA, USA; ${ }^{2}$ Department of Surgery, University of California, Los \\ Angeles, CA, USA; ${ }^{3}$ Department of Biostatistics, University of California, Los Angeles, CA, USA
}

\begin{abstract}
Background: Hepatitis $\mathrm{C}$ (HCV) direct acting antiviral agents (DAAs) are safe, effective, and tolerable. Most contraindications to interferon-based treatment are no long applicable. The aims of this study were to understand the predictors of approval to drug accessibility. Methods: We studied all consecutive patients with HCV prescribed DAAs between October 2014 and July 2015. Data on demographic, socioeconomic status, comorbidities, baseline laboratory values, and assessment of liver disease severity, insurance, and specialty pharmacy type were collected. Multivariate analyses were performed to identify predictors of prescription approval. Results: In total, 410 patients were prescribed DAAs between October 2014 and July 2015. Of those, 332 (81\%) patients were insurance approved for therapy. Of the 332 patients accepted, 251 were accepted after the first prescription attempt, and 38 were accepted after the second and third attempts. The number of attempts for the other 43 approved patients was unknown. Older age $(p=0.001)$, employment $(p=0.001)$, lack of comorbidities $(p=0.02)$, liver transplantation $(p=0.018)$, and advanced liver disease $(p=0.001)$ were more likely associated with obtaining approval. Household income was not associated with insurance approval. In the multivariate analysis, Medicare insurance (odds ratio [OR]) $2.67,95 \%$ confidence interval [CI] 0.96-7.20), lack of nonliver comorbidities (OR 2.72, 95\% CI 1.35-5.43), and the presence of advanced liver disease (OR 1.82, 95\% CI 1.04-3.24) independently predicted drug approval. Conclusion: Despite the availability of DAAs for $\mathrm{HCV}$, barriers from insurance carriers continue to impair widespread use. Patients with advanced liver disease, Medicare, and without comorbidities are most likely to be insurance approved for DAAs.
\end{abstract}

Keywords: Hepatitis C; Healthcare access; Antiviral therapy.

Abbreviations: 3D, ombitasvir-paritaprevir-ritonavir and dasabuvir; AASLD, American Association for the Study of Liver Diseases; ALT, alanine transaminase AST, aspartate transaminase; CI, confidence interval; CPD, cardiopulmonary disease; DAAs, direct acting agents; HBV, hepatitis B virus; HCC, hepatocellular carcinoma; HCV, hepatitis C virus; HIV, human immunodeficiency virus; HMO, health maintenance organization; IDSA, Infectious Diseases Society of America INR, International Normalized Ratio; IQR, interquartile range; OR, odds ratio PPO, preferred provider organization; SD, standard deviation; SVR, sustained viral response; ZCTA, zip code tabulation area.

Received: 17 March 2016; Revised: 12 April 2016; Accepted: 14 April 2016 DOI: $10.14218 / \mathrm{JCTH} .2016 .00011$.

Correspondence to Sammy Saab, Pfleger Liver Institute, UCLA Medical Center, 200 Medical Plaza, Suite 214, Los Angeles, CA 90095, USA. Tel: +1-310-206 6705, Fax: +1-310-206-4197, E-mail: SSaab@mednet.ucla.edu
(C) 2016 The Second Affiliated Hospital of Chongqing Medical University. Published by XIA \& HE Publishing Inc. All rights reserved.

\section{Introduction}

Up to 5-7 million Americans are believed to be infected with chronic hepatitis $\mathrm{C}(\mathrm{HCV})$ Most of these individuals are unaware of their disease and are in the baby-boomer age group. ${ }^{1}$ Chronic hepatitis $C$ infection is an important medical concern that has both hepatic and extrahepatic manifestation. ${ }^{2}$ The viral infection can lead to cirrhosis, hepatocellular carcinoma (HCC), and liver failure. ${ }^{2-4}$ Indeed, HCV is the most common indication for liver transplantation in the United States. ${ }^{5}$ Extrahepatic manifestations, such as cryoglobulinemia and kidney disease, are also important causes of morbidity and mortality. 6,7

Achieving a sustained viral response (SVR) is associated with a number of improved clinical outcomes, including liverrelated outcomes and overall survival. ${ }^{8,9}$ Interferon has been the cornerstone of antiviral therapy for almost 2 decades. ${ }^{10}$ However, its utility is limited by a number of contraindications, such as uncontrolled depression and autoimmune disorders. ${ }^{11,12}$ The introduction of all-oral direct-acting agents (DAAs) has revolutionized the treatment of HCV. ${ }^{13,14}$ Compared to interferon, DAAs have been shown to increase SVR and improve tolerability compared to interferon. Few serious adverse effects are seen with DAAs, and rarely do patients discontinue use of DAAs due to adverse effects. ${ }^{15}$

Antiviral therapy with DAAs has been not only been demonstrated to be safer, more effective, and better tolerated than interferon-based therapy but also more cost effective. ${ }^{16-20}$ Nevertheless, DAAs are expensive and access to these drugs is not guaranteed. Thus, we examined the accessibility of these drugs to patients with HCV. We hypothesized that there are substantial barriers to HCV antiviral therapy for patients, even after specialty referral.

\section{Patient and Methods}

\section{Study populations}

Consecutive HCV patients treated with DAAs at the University of California Los Angeles (UCLA) since the approval of sofosbuvir/ledipasvir were identified through an administrative UCLA database. The study period was between October 
2014 and July 2015. We collected demographic information, such as gender, age, and ethnicity. Baseline laboratory, radiological, and histological results, as applicable, were also recorded. Laboratory tests were obtained within 30 days of the prescription being sent to pharmacy. Liver disease severity, defined through clinical findings, laboratory tests, liver biopsy, and/or radiological evaluation, was classified as either advanced (stage 3-4) or nonadvanced (stages $0-2$ ). Decompensated manifestations were defined by the presence of ascites, encephalopathy, variceal bleeding or esophageal varices without bleeding, liver cancer, or jaundice. Extrahepatic manifestations were defined by the presence of debilitation/fatigue, type 2 diabetes mellitus, porphyria cutanea tarda, cryoglobulinemia, lymphoma, or vasculitis. Nonliver comorbidities were defined by the presence of cardiopulmonary disease, hemodialysis, stroke, nonHCC malignancy, human immunodeficiency virus (HIV), and diabetes.

Generally, prescriptions were sent to specialty pharmacies. These pharmacies were responsible for the completion of authorization forms and, if necessary, appeals for drug approvals. Insurance carrier and specialty pharmacy were noted. Pharmacies were stratified in our analysis according to whether they were privately or publically owned (company traded on a stock exchange). The stratification of pharmacies was important to exclude effort bias by the two types of pharmacies. Patient income was estimated by residential zip code and zip code tabulation area (ZCTA) through the United States Census Bureau. ${ }^{21}$ The study was approved by the Institutional Review Board. Patient consent was not required since this was a retrospective analysis. There was no funding for this study.

\section{Outcomes}

Our main outcome was insurance approval for oral antiviral therapy. We recorded prescription approval or denial for each patient. The time between prescription submission and the pharmacy's decision was recorded. The number and the decision of appeals were also documented. Generally, prescription packets containing necessary study results and clinical information, including indication for antiviral therapy, were sent to specialty pharmacies. If the insurance provider declined drug approval, it was our practice to appeal the decision up to two times.

\section{Statistical Analysis}

Data are presented as mean \pm standard deviation (SD), median with interquartile range (IQR), or number in group with percent of group based on the distribution of the data. Univariate analysis was performed using a t-test for normally distributed continuous data, Wilcoxon-Rank Sum test for nonnormally distributed continuous data, and Fisher's exact test or Chi-sqaure test for discrete data. We used a multivariate logistic regression model to derive adjusted oddratios (OR) for predictors of patients that were approved for DAAs by their insurance provider. The multivariate logistic regression model was built using variables with a $p$ value below 0.10 on univariate analysis. All tests were two-sided, and a $p$ value below 0.05 indicated statistical significance. The R Statistical Programming Environment was used to conduct analysis (R Core Team Vienna, Austria).

\section{Results}

During our study period, 410 patients were prescribed all oral antiviral therapy. Baseline demographic information is found in Table 1. The mean age ( \pm SD) of our cohort was 59.6 $( \pm 10.9)$ years. The majority of patients were male. Almost $50 \%$ of our cohort was unemployed, and most patients were insured with Medicare. Less than $10 \%$ of the patient cohort had a nonliver related comorbidity. Extrahepatic manifestations were found in over a quarter of patients, and $22.4 \%$ of patients had some manifestation of hepatic decompensation. Almost $20 \%$ of the patient cohort was transplant recipients. Of the employed patients, most had incomes between $\$ 50,000$ and $\$ 100,000$.

Of the nontransplant recipients, $58.7 \%$ of the patients were classified as having advanced liver disease. Baseline laboratory test values are shown in Table 2. Genotype 1 was the predominant viral genotype and was found in $85 \%$ of patients. The mean HCV viral load was 5,430,135 IU/mL. The mean aspartate aminotransferase (AST), alanine aminotransferase (ALT), total bilirubin, and platelet count were $63 \mathrm{IU} / \mathrm{mL}, 70 \mathrm{IU} / \mathrm{mL}$, $0.88 \mathrm{mg} / \mathrm{dL}$, and $170 \times 10^{3} / \mu \mathrm{L}$ respectively.

The insurance approval rate for our cohort was $81.0 \%$ (332/410), and $36.3 \%$ and $63.7 \%$ of the prescriptions were sent to privately and publically owned pharmacies, respectively. Of the 332 patients approved for therapy, 251 were approved without the need for appeal to the insurance company. Thirty-four were approved after one appeal, and four were approved after the second appeal. Information on the time from submission to insurance decision was known in 368 patients, and the mean ( \pm SD) time from submission to drug approval was 28.1 ( \pm 46.0 ) days. Patients with Medicaid were less likely to be approved and waited the longest for the final decision (Fig. 2). The likelihood of drug therapy approval varied according to insurance plan: Medicaid $(80 \%, 36 / 45)$, Medicare $(92 \%, 153 / 166)$, non-Medicaid health maintenance organization (HMO) $(78 \%, 42 / 54)$, and preferred provider organization (PPO) $(70 \%, 101 / 145)$. Drug therapies are shown on Table 3.

Predictors of approval were age $(p=0.001)$, work status $(p=0.001)$, lack of comorbidities $(p=0.02)$, liver transplantation $(p=0.018)$, and severity of liver disease $(p=0.001)$. The results of multivariate analysis identified Medicare insurance (OR 2.67, 95\% confidence interval [CI]), lack of comorbidities (OR 2.72, 95\% CI 1.35-5.43), and the presence of advanced liver disease (OR $1.82,95 \%$ CI 1.04-3.24) as independent predictors of drug approval (Table 4).

\section{Discussion}

The results of our study demonstrate the insurance accessibility limitations for patients with chronic hepatitis $\mathrm{C}$ infection in our practice. The overall insurance approval was $81 \%$. Predictors of approval were age, work status, liver transplantation, type of insurance, severity of liver disease, and the lack of medical comorbidities. The presence of extrahepatic manifestations, hepatic decompensation, HCC, and other co-existent liver diseases were not found to be associated with the likelihood of obtaining DAAs. Initially, the American Association for the Study of Liver Diseases (AASLD)/Infectious Diseases Society of America (IDSA) joint guidance recommended prioritization of patients with HCV and highlighted liver transplant recipients and patients with severe liver damage as a highest prioritization. More recently, the 
Saab S. et al: Access to hepatitis C antiviral therapy

Table 1. Demographics and baseline results

\begin{tabular}{|c|c|c|c|c|c|c|}
\hline Characteristics & $\begin{array}{l}\text { Overall } \\
n / N(\%) \\
N=410\end{array}$ & $\begin{array}{l}\text { Approved } \\
n / N(\%) \\
N=332\end{array}$ & $\begin{array}{l}\text { Denied } \\
n / N(\%) \\
N=78\end{array}$ & OR & $95 \% \mathrm{CI}$ & $p$-Value \\
\hline Mean age - years & $59.6(10.9)$ & $60.5(10.5)$ & $55.6(11.7)$ & & & 0.001 \\
\hline Gender & & & & & & 1 \\
\hline Female & $172 / 410(42 \%)$ & $139 / 332(41.9 \%)$ & $33 / 78(42.3 \%)$ & Reference & & \\
\hline Male & $238 / 410(58 \%)$ & $193 / 332(58.1 \%)$ & $45 / 78(57.7 \%)$ & 1.02 & $0.61-1.67$ & \\
\hline Work status & & & & & & 0.001 \\
\hline Disabled & $103(25.1 \%)$ & $92(27.7 \%)$ & $11(14.1 \%)$ & Reference & & \\
\hline Employed & $193(47.1 \%)$ & $143(43.1 \%)$ & $50(64.1 \%)$ & 0.34 & $(0.16-0.67)$ & \\
\hline Retired & $86(21 \%)$ & $77(23.2 \%)$ & $9(11.5 \%)$ & 1.02 & $(0.4-2.66)$ & \\
\hline Unemployed & $28(6.8 \%)$ & $20(6 \%)$ & $8(10.3 \%)$ & 0.3 & $(0.11-0.86)$ & \\
\hline $\begin{array}{l}\text { Non-Liver } \\
\text { comorbidities }\end{array}$ & $59 / 410(14.4 \%)$ & $41 / 332(12.3 \%)$ & $18 / 78(23.1 \%)$ & 0.47 & $0.26-0.89$ & 0.02 \\
\hline $\begin{array}{l}\text { Co-existent Liver } \\
\text { Diseases }\end{array}$ & $20 / 410(4.9 \%)$ & $14 / 332(4.2 \%)$ & $6 / 78(7.7 \%)$ & 0.53 & $0.2-1.53$ & 0.238 \\
\hline $\begin{array}{l}\text { Extra-hepatic } \\
\text { manifestations }\end{array}$ & $116 / 410(28.3 \%)$ & $91 / 332(27.4 \%)$ & $25 / 78(32.1 \%)$ & 0.8 & $0.47-1.38$ & 0.406 \\
\hline $\begin{array}{l}\text { Hepatic } \\
\text { decompensations }\end{array}$ & $84 / 410(20.5 \%)$ & $74 / 332(22.3 \%)$ & $10 / 78(12.8 \%)$ & 1.95 & $1.0-4.2$ & 0.063 \\
\hline $\mathrm{HCC}$ & $4(1 \%)$ & $2(0.6 \%)$ & $2(2.6 \%)$ & 0.23 & $0.03-1.94$ & 0.165 \\
\hline $\begin{array}{l}\text { Liver transplant } \\
\text { recipient }\end{array}$ & $83 / 410(20.2 \%)$ & $75 / 332(22.6 \%)$ & $8 / 78(10.3 \%)$ & 2.55 & $1.24-5.97$ & 0.018 \\
\hline $\begin{array}{l}\text { Severity of Liver } \\
\text { Disease } \\
\text { (Non-transplant) }\end{array}$ & & & & & & 0.001 \\
\hline Advanced & $152 / 327(46.5 \%)$ & $131 / 257(51 \%)$ & $21 / 70(30 \%)$ & Reference & & \\
\hline Non-advanced & $175 / 327(53.5 \%)$ & $126 / 257(49 \%)$ & $49 / 70(70 \%)$ & 0.42 & $0.24-0.7$ & \\
\hline Income & & & & & & 0.2 \\
\hline$<50,000$ & 88/399 (22\%) & $74 / 322(23 \%)$ & $14 / 77(18.2 \%)$ & Reference & & \\
\hline $50,000-100,000$ & $266 / 399(66.7 \%)$ & $216 / 322(67.1 \%)$ & $50 / 77(64.9 \%)$ & 0.82 & $0.41-1.53$ & \\
\hline$>100,000$ & 45/399 (11.3\%) & $32 / 322(9.9 \%)$ & $13 / 77(16.9 \%)$ & 0.47 & $0.2-1.11$ & \\
\hline $\begin{array}{l}\text { Percent below } \\
\text { poverty, } \\
\text { median (IQR) }\end{array}$ & $11.1(8.2-18.2)$ & $11.8(8.2-18.6)$ & $\begin{array}{l}10.3(7.9- \\
15.9)\end{array}$ & 1.02 & $0.99-1.06$ & 0.172 \\
\hline Pharmacy & $N=410$ & $N=332$ & $N=78$ & & & 0.602 \\
\hline Privately owned & $149 / 410(36.3 \%)$ & $123 / 332(37 \%)$ & $26 / 78(33.3 \%)$ & Reference & & \\
\hline Publically traded & $261 / 410(63.7 \%)$ & 209/332 (63\%) & $52 / 78(66.7 \%)$ & 0.85 & $0.5-1.42$ & \\
\hline Type of insurance & & & & & & $<0.001$ \\
\hline Medicaid & $45(11 \%)$ & $36(10.8 \%)$ & $9(11.5 \%)$ & Reference & & \\
\hline Medicare & $166(40.5 \%)$ & $153(46.1 \%)$ & $13(16.7 \%)$ & 2.94 & $(1.14-7.37)$ & \\
\hline Non-Medicaid HMO & $54(13.2 \%)$ & $42(12.7 \%)$ & $12(15.4 \%)$ & 0.88 & $(0.32-2.3)$ & \\
\hline$P P O$ & $145(35.4 \%)$ & $101(30.4 \%)$ & $44(56.4 \%)$ & 0.57 & $(0.24-1.25)$ & \\
\hline $\begin{array}{l}\text { Days from Rx } \\
\text { request } \\
\text { to Insurance } \\
\text { Decision } \\
\text { Median (IQR) - days }\end{array}$ & $10(3-27)$ & $8(2-24)$ & $16(5-54)$ & 0.99 & 0.99-1 & 0.001 \\
\hline
\end{tabular}

Abbreviations: PPO, Preferred Provider Organization; HMO, Health Maintenance Organization; CPD, Cardiopulmonary Disease; HCC, Hepatocellular Carcinoma; IQR, Interquartile Range. 
Saab S. et al: Access to hepatitis C antiviral therapy

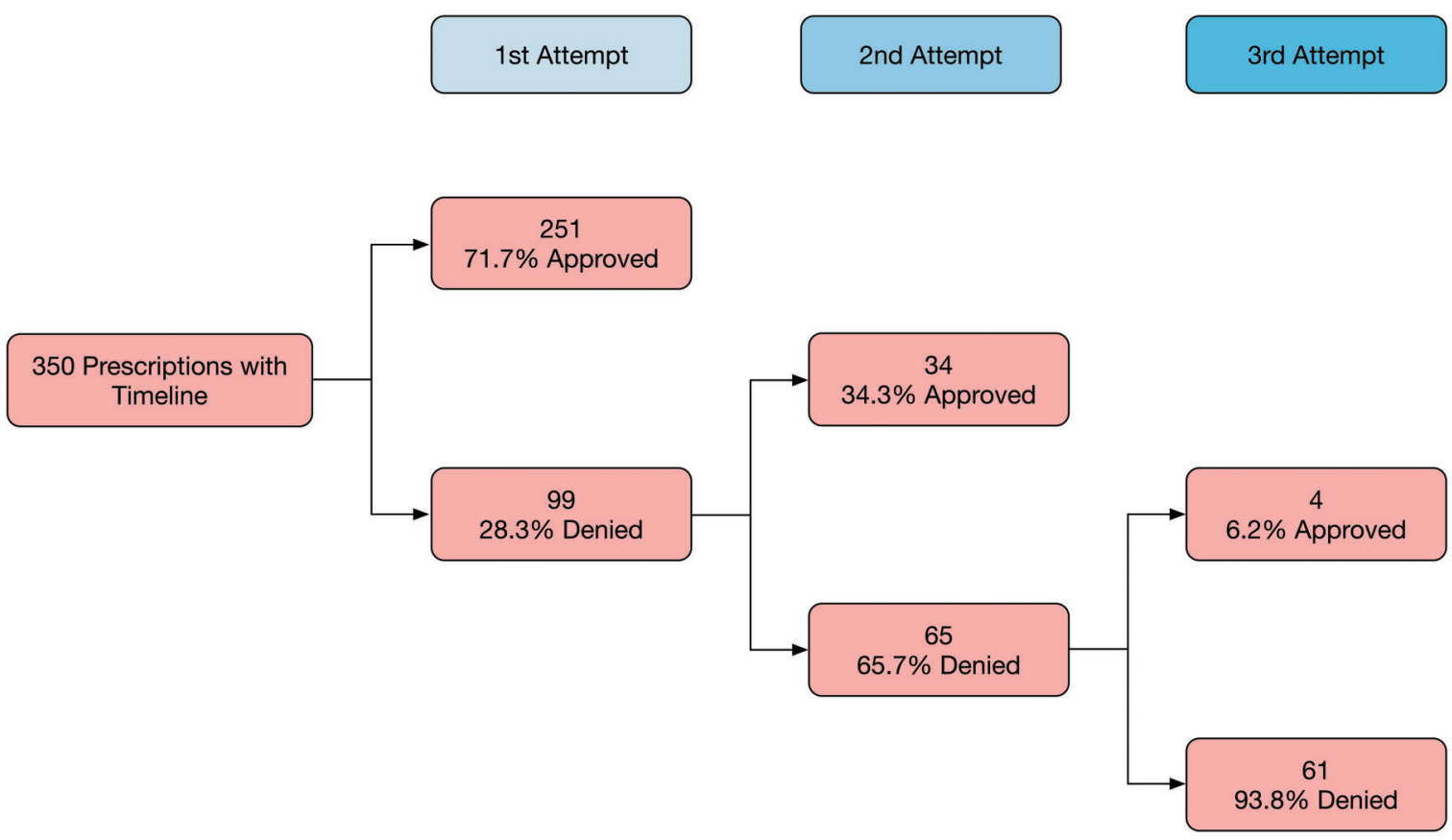

Fig. 1. Flow chart of approvals and denial for patients with timeline of attempts.

Table 2. Baseline laboratory results

\begin{tabular}{|c|c|c|c|c|c|c|}
\hline Characteristics & $\begin{array}{l}\text { Overall } n / N(\%) \\
N=410\end{array}$ & $\begin{array}{l}\text { Approved } \mathrm{n} / \mathrm{N}(\%) \\
\mathrm{N}=332\end{array}$ & $\begin{array}{l}\text { Denied } n / N(\%) \\
N=78\end{array}$ & OR & $95 \% \mathrm{CI}$ & $p$-Value \\
\hline Genotype & & & & & & 0.803 \\
\hline 1 & $349 / 410(85.1 \%)$ & $283 / 332(85.2 \%)$ & $66 / 78(84.6 \%)$ & Reference & & \\
\hline 2 & $22 / 410(5.4 \%)$ & $19 / 332(5.7 \%)$ & $3 / 78(3.8 \%)$ & 1.48 & $0.49-6.42$ & \\
\hline 3 & $30 / 410(7.3 \%)$ & $23 / 332(6.9 \%)$ & $7 / 78(9.0 \%)$ & 0.77 & $0.33-2$ & \\
\hline 4 & $9 / 410(2.2 \%)$ & $7 / 332(2.1 \%)$ & $2 / 78(2.6 \%)$ & 0.82 & $0.19-5.56$ & \\
\hline $\begin{array}{l}\text { Viral load }(\mathrm{IU} / \mathrm{mL}) \\
\text { Median }(I O R)\end{array}$ & $\begin{array}{l}2,010,000 \\
(579,500-5,405,000)\end{array}$ & $\begin{array}{l}2,100,000 \\
(57,8750-5,585,000)\end{array}$ & $\begin{array}{l}1702,612 \\
(662,000-4,310,000)\end{array}$ & - & - & 0.579 \\
\hline $\begin{array}{l}\mathrm{AST}(\mathrm{U} / \mathrm{L}) \\
\text { Median }(I Q R)\end{array}$ & $46.5(32-76.2)$ & $48(31-77)$ & $45(35.2-72.8)$ & - & - & 0.644 \\
\hline $\begin{array}{l}\mathrm{ALT}(\mathrm{U} / \mathrm{L}) \\
\text { Median }(I Q R)\end{array}$ & $54(32-89)$ & $54(30-89.5)$ & $58.5(39-87.8)$ & - & - & 0.197 \\
\hline $\begin{array}{l}\text { Bilirubin, } \\
\text { Total }(\mathrm{mg} / \mathrm{dL}) \\
\text { Median }(I Q R)\end{array}$ & $0.5(0.4-0.8)$ & $0.6(0.4-0.8)$ & $0.5(0.4-0.9)$ & - & - & 0.37 \\
\hline $\begin{array}{l}\text { Alkaline } \\
\text { phosphatase (U/L) } \\
\text { Median }(I Q R)\end{array}$ & $83(63-111)$ & $86(65.2-114)$ & $73(59.2-100)$ & - & - & 0.027 \\
\hline $\begin{array}{l}\text { Albumin }(\mathrm{g} / \mathrm{dL}) \\
\text { Median }(I Q R)\end{array}$ & $4.3(3.8-4.5)$ & $4.2(3.8-4.4)$ & $4.4(4-4.6)$ & - & - & 0.002 \\
\hline $\begin{array}{l}\text { Platelet count } \\
\left(\times 10 \mathrm{E}^{3} / \mathrm{uL}\right) \\
\text { Median }(I Q R)\end{array}$ & 169 (109.5-227) & $161(103-223)$ & $181(141.5-238.5)$ & - & - & 0.019 \\
\hline $\begin{array}{l}\text { Creatinine }(\mathrm{mg} / \mathrm{dL}) \\
\text { Median }(I Q R)\end{array}$ & $0.9(0.8-1.1)$ & $0.9(0.8-1.1)$ & $0.8(0.7-1)$ & - & - & 0.077 \\
\hline INR Median (IQR) & $1.1(1.1-1.2)$ & $1.1(1-1.2)$ & $1.1(1.1-1.2)$ & - & - & 0.89 \\
\hline
\end{tabular}

Abbreviations: AST, Aspartate Transaminase; ALT, Alanine Transaminase; INR, International Normalized Ratio; IQR, Interquartile Range. 
Saab S. et al: Access to hepatitis C antiviral therapy

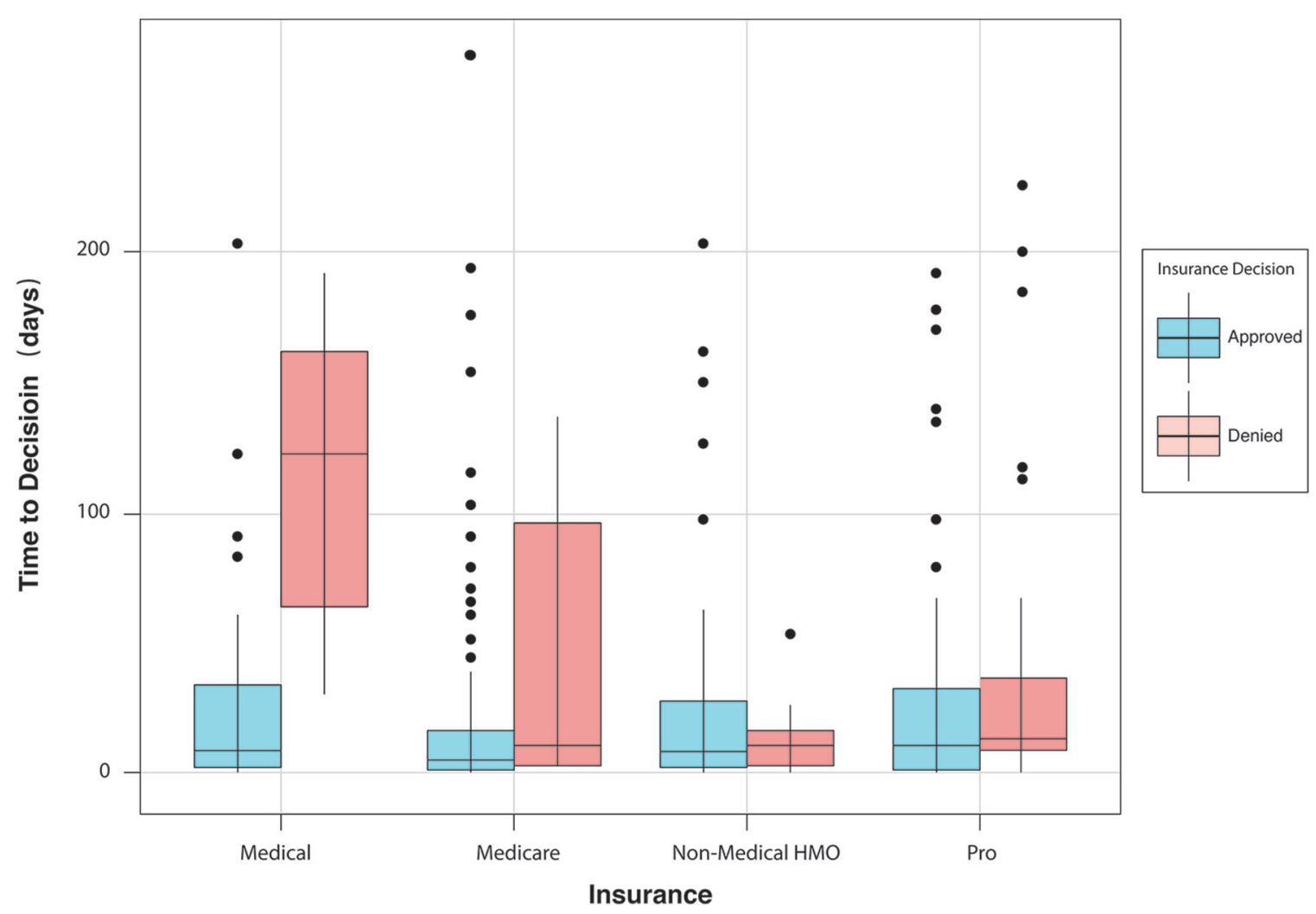

Fig. 2. Time to decision by insurance type.

same joint guidance recommended all patients should be treated for HCV because of the potential for extrahepatic manifestations. ${ }^{22}$

Several other studies have also highlighted the insurance barriers to obtaining DAAs. For instance, the study by Do et al. described an overall insurance approval of $77.5 \% .^{23}$ The major predictors of drug approval were public insurance and advanced liver disease. In contrast, our study stratified patients based on public insurance and found there was a substantive difference between patients with Medicaid and Medicare insurances. The results of a separate study by Re et al., which was recently presented at the AASLD national meeting, revealed an insurance approval of $84 \% .{ }^{24}$ Similar to our findings, they found a high denial rate for DAAs therapy in patients with Medicaid insurance. In addition, patients with Medicare insurance generally had higher approval rates.

Patients with Medicare were more likely than any other insurance to be approved for DAAs. Of the 166 patients with Medicare, 153/166 (92.2\%) were approved for treatment. The ease of Medicare patients to start antiviral therapy may serve as a disincentive for select insurance carriers to deny patients with the expectation they will be eventually approved. The criteria for drug approval vary across insurance companies. For instance, Medicaid requires a minimal fibrosis stage of 2 to be approved for treatment, whereas a particular PPO insurance company limits the use of DAAs to patients with at least bridging fibrosis assessed only through a liver biopsy and elastrography. ${ }^{25}$

Table 3. Treatment regimens

\begin{tabular}{llll}
\hline Characteristics & Overall & Approved n/N (\%) & Denied n/N (\%) \\
\hline Treatment regimen & & $\mathrm{N}=332$ & $\mathrm{~N}=78$ \\
Ledipasvir/Sofosbuvir & 324 & $261 / 332(78.6 \%)$ & $63 / 78(80.8 \%)$ \\
Ledipasvir/Sofosbuvir + Ribavarin & 39 & $30 / 332(9.0 \%)$ & $9 / 78(11.5 \%)$ \\
Sofosbuvir + Ribavarin & 37 & $33 / 332(9.9 \%)$ & $4 / 78(5.1 \%)$ \\
Sofosbuvir + Simeprevir & 2 & $1 / 332(0.3 \%)$ & $1 / 78(1.3 \%)$ \\
3D & 12 & $6 / 332(1.8 \%)$ & $6 / 78(7.7 \%)$ \\
3D + Ribavarin & 3 & $1 / 332(0.3 \%)$ & $2 / 78(2.6 \%)$ \\
\hline
\end{tabular}

Abbreviation: 3D, Ombitasvir-Paritaprevir-Ritonavir and Dasabuvir. 
Saab S. et al: Access to hepatitis C antiviral therapy

Table 4. Results of multivariate analysis

\begin{tabular}{llll}
\hline Characteristics & OR & $95 \%$ CI & $p$-value \\
\hline Age (years) & 1.02 & $0.99-1.04$ & \\
Work status & & & \\
$\quad$ Disabled & Reference & 0.261 \\
Employed & 0.56 & $0.24-1.26$ \\
$\quad$ Retired & 0.68 & $0.24-2.01$ & $0.12-1.17$ \\
$\quad$ Unemployed & 0.37 & & \\
Insurance & & & 0.023 \\
Medicaid HMO & Reference & $0.96-7.2$ \\
$\quad$ Medicare & 2.66 & $0.39-3.1$ \\
$\quad$ Non-Medicaid HMO & 1.11 & $0.31-1.82$ \\
PPO & 0.78 & $1.35-5.43$ \\
Lack of comorbidities & 2.72 & $0.41-1.34$ \\
Extrahepatic manifestations & 0.74 & $0.85-4.46$ \\
Liver transplant recipient & 1.85 & & 0.006 \\
Stage of fibrosis & & $1.04-3.24$ \\
$\quad$ Non-advanced fibrosis & Reference & 0.313 \\
Advanced fibrosis & 1.82 & 0.035 \\
\hline
\end{tabular}

Abbreviations: PPO, Preferred Provider Organization; HMO, Health Maintenance Organization.

Although studies have shown consistently that antiviral therapy with DAAs for HCV is cost effective, almost $20 \%$ of our patient cohort was declined treatment by the insurance carrier. ${ }^{16-20} \mathrm{~A}$ potential reason for this lack of approval is the upfront costs associated with curing hepatitis $C$. The average wholesale cost for an antiviral therapy course is almost $\$ 90,000$, and the benefits of curing HCV are not realized for years after SVR is achieved. For instance, the cost effectiveness of treating HBV has been shown, even though the clinical impact is not found for many years, because the treatment costs are amortized. ${ }^{26,27}$

There are a number of limitations to our study. First, our analysis was limited by the start point of our specialty hepatology clinic. Multiple barriers to therapy exist prior to when the patients walks into our office, and these can be stratified into patient, provider, and system constructs. ${ }^{30-32}$ Second, the results of our study may not be generalizable to other practices, as the patients in our cohort were prescribed DAAs at an academic center with experienced hepatologists and a dedicated staff. The exclusive use of a specialist, who may have an inherent interest in drug approval, could have influenced the likelihood of DAA approval. Another limitation is the availability of DAAs from all drug formularies and the fluidity of treatment criteria. The large cohort and the long entry study period should hopefully mitigate this limitation and the effects on our results. Lastly, our results pertain to the United Health care system, and the findings cannot be extrapolated to other regions of the World. For instance, in many countries, public, not private, medical insurance predominates. As a result, antiviral therapies are funded by the government and accessibility does not depend on insurance approval.

Despite the effectiveness, safety, and tolerability of DAAs, barriers to access these medications continue, even at specialty hepatology clinics. The results of our study highlight that patients with advanced liver disease, Medicare, and those without comorbidities are most likely to be insurance approved for DAAs.

\section{Conflict of interest}

None

\section{Author contributions}

Study concept and design (SS, SB, TF, CW, DE), data acquisition (MJ, TF, CW, SB), data analysis and interpretation (MJ, JG, DE), drafting of the manuscript (SS, MJ, TF, CW), critical revision of the manuscript (SS, SB, JG, MJ), statistical analysis (JG, DE), administrative, technical, or study supervision (SS, DE).

\section{References}

[1] Chak E, Talal AH, Sherman KE, Schiff ER, Saab S. Hepatitis C virus infection in USA: an estimate of true prevalence. Liver Int 2011;31:1090-1101. doi: 10. 1111/j.1478-3231.2011.02494.x.

[2] Younossi ZM, Kanwal F, Saab S, Brown KA, El-Serag HB, Kim WR, et al. The impact of hepatitis $C$ burden: an evidence-based approach. Aliment Pharmacol Ther 2014;39:518-531. doi: 10.1111/apt.12625.

[3] Freeman AJ, Dore GJ, Law MG, Thorpe M, Von Overbeck J, Lloyd AR, et al. Estimating progression to cirrhosis in chronic hepatitis $C$ virus infection. Hepatology. 2001;34:809-816. doi: 10.1053/jhep.2001.27831.

[4] Kanwal F, Hoang T, Kramer JR, Asch SM, Goetz MB, Zeringue A, et al. Increasing prevalence of $\mathrm{HCC}$ and cirrhosis in patients with chronic hepatitis $\mathrm{C}$ virus infection. Gastroenterology. 2011;140:1182-1188.e1. doi: 10.1053/j.gastro. 2010.12.032.

[5] Kim WR, Stock PG, Smith JM, Heimbach JK, Skeans MA, Edwards EB, et al. OPTN/SRTR 2011 Annual Data Report: liver. Am J Transplant 2013;1:73-102. doi: $10.1111 /$ ajt.12021.

[6] Stefanova-Petrova DV, Tzvetanska AH, Naumova EJ, Mihailova AP, Hadjiev EA, Dikova RP, et al. Chronic hepatitis C virus infection: prevalence of extrahepatic manifestations and association with cryoglobulinemia in Bulgarian 
patients. World J Gastroenterol. 2007;13:6518-6528. doi: 10.3748/wjg.13. 6518

[7] Lee MH, Yang HI, Lu SN, Jen CL, You SL, Wang LY, et al. Chronic hepatitis C virus infection increases mortality from hepatic and extrahepatic diseases: a community-based long-term prospective study. J Infect Dis. 2012;206:469-477. doi: $10.1093 /$ infdis/jis385.

[8] Koh C, Heller T, Haynes-Williams V, Hara K, Zhao X, Feld J], et al. Long-term outcome of chronic hepatitis $\mathrm{C}$ after sustained virological response to interferonbased therapy. Aliment Pharmacol Ther 2013;37:887-894. doi: 10.1111/apt. 12273.

[9] van der Meer AJ, Veldt BJ, Feld JJ, Wedemeyer H, Dufour JF, Lammert F, et al. Association between sustained virological response and all-cause mortality among patients with chronic hepatitis $C$ and advanced hepatic fibrosis. JAMA. 2012;308:2584-2593. doi: 10.1001/jama.2012.144878.

[10] Saab S, Jackson C, Nieto J, Francois F. Hepatitis C in African Americans. Am J Gastroenterol. 2014;109:1576-1584. doi: 10.1038/ajg.2014.243.

[11] Russo MW, Fried MW. Side effects of therapy for chronic hepatitis C. Gastroenterology. 2003;124:1711-1719. doi: 10.1016/S0016-5085(03)00394-9.

[12] Slim J, Afridi MS. Managing adverse effects of interferon-alfa and ribavirin in combination therapy for HCV. Infect Dis Clin North Am. 2012;26:917-929. doi: $10.1016 / j$.idc.2012.08.006.

[13] Webster DP, Klenerman P, Dusheiko GM. Hepatitis C. Lancet. 2015;385: 1124-1135. doi: 10.1016/S0140-6736(14)62401-6.

[14] Feeney ER, Chung RT. Antiviral treatment of hepatitis C. BMJ. 2014;348: g3308. doi: $10.1136 / \mathrm{bmj} . \mathrm{g} 3308$.

[15] Boccaccio V, Bruno S. Optimal management of patients with chronic hepatitis C and comorbidities. Liver Int. 2015;35:35-43. doi: 10.1111/liv.12712.

[16] Chhatwal J, Kanwal F, Roberts MS, Dunn MA. Cost-effectiveness and budget impact of hepatitis $C$ virus treatment with sofosbuvir and ledipasvir in the United States. Ann Intern Med. 2015;162:397-406. doi: 10.7326/M141336.

[17] Najafzadeh M, Andersson K, Shrank WH, Krumme AA, Matlin OS, Brennan T, et al. Cost-effectiveness of novel regimens for the treatment of hepatitis C virus. Ann Intern Med. 2015;162:407-419. doi: 10.7326/M14-1152.

[18] Hagan LM, Sulkowski MS, Schinazi RF. Cost analysis of sofosbuvir/ribavirin versus sofosbuvir/simeprevir for genotype 1 hepatitis $C$ virus in interferonineligible/intolerant individuals. Hepatology. 2014;60:37-45. doi: 10.1002/ hep. 27151.

[19] Younossi ZM, Park H, Saab S, Ahmed A, Dieterich D, Gordon SC. Costeffectiveness of all-oral ledipasvir/sofosbuvir regimens in patients with chronic hepatitis $\mathrm{C}$ virus genotype 1 infection. Aliment Pharmacol Ther. 2015;41:544-563. doi: 10.1111/apt.13081.

[20] Chahal HS, Marseille EA, Tice JA, Pearson SD, Ollendorf DA, Fox RK, et al. Cost-effectiveness of Early Treatment of Hepatitis C Virus Genotype 1 by Stage of Liver Fibrosis in a US Treatment-Naive Population. JAMA Intern Med. 2016;176:65-73. doi: 10.1001/jamainternmed.2015.6011.

[21] http://factfinder.census.gov/faces/nav/jsf/pages/community_facts.xhtml, accessed August 2015.

[22] www.HCVguidelines.org. Accessed November, 2015.

[23] Do A, Mittal Y, Liapakis A, Cohen E, Chau H, Bertuccio C, et al. Drug Authorization for Sofosbuvir/Ledipasvir (Harvoni) for Chronic HCV Infection in a Real-World Cohort: A New Barrier in the HCV Care Cascade. PLoS One. 2015;10:e0135645. doi: 10.1371/journal.pone.0135645.

[24] Lo Re V, Gowda C, Urick PN, Halladay J, Binkley A, Carbonari DM, et al. Incidence and determinants of denial of DAA therapy by type of insurance during the first 6 months of the modern HCV treatment era. AASLD 2015. 13-17 Nov, 2015. San Francisco.

[25] http://www.dhcs.ca.gov/Pages/HepatitisC.aspx. Accessed. December 2015.

[26] Yuan Y, Iloeje UH, Hay J, Saab S. Evaluation of the cost-effectiveness of entecavir versus lamivudine in hepatitis BeAg-positive chronic hepatitis B patients. J Manag Care Pharm. 2008;14:21-33. doi: 10.18553/jmcp.2008. 14.1.21.

[27] Dakin H, Bentley A, Dusheiko G. Cost-utility analysis of tenofovir disoproxil fumarate in the treatment of chronic hepatitis B. Value Health. 2010;13: 922-933. doi: 10.1111/j.1524-4733.2010.00782.x.

[28] Ly KN, Xing J, Klevens RM, Jiles RB, Ward JW, Holmberg SD. The increasing burden of mortality from viral hepatitis in the United States between 1999 and 2007. Ann Intern Med. 2012;156:271-278. doi: 10.7326/0003-4819156-4-201202210-00004.

[29] Chen DS, Locarnini S, Wallace J. From the big three to the big four. Lancet Infect Dis. 2015;15:626-627. doi: 10.1016/S1473-3099(15)00026-2.

[30] Stepanova M, Younossi ZM. Interferon-free regimens for chronic hepatitis C: barriers due to treatment candidacy and insurance coverage. Dig Dis Sci. 2015;60:3248-3251. doi: 10.1007/s10620-015-3709-6.

[31] McGowan CE, Monis A, Bacon BR, Mallolas J, Goncales FL, Goulis I, et al. A global view of hepatitis C: physician knowledge, opinions, and perceived barriers to care. Hepatology. 2013;57:1325-1332. doi: 10.1002/hep. 26246.

[32] Afdhal NH, Zeuzem S, Schooley RT, Thomas DL, Ward JW, Litwin AH, et al. The new paradigm of hepatitis $C$ therapy: integration of oral therapies into best practices. J Viral Hepat. 2013;20:745-760. doi: 10.1111/jvh.12173. 